\section{B A Institute of \\ YK Business Administration \\ 六下 \\ Karachi \\ Leadership and Ideas for Tomorrow}

Business Review

Volume 6 Issue 2 July-December 2011

7-1-2011

\title{
Type A-B personality and locus of control: A combined factor determining job satisfaction
}

\author{
Afia Hanif \\ Bahauddin Zakaryia University, Multan, Pakistan \\ Sarwat Sultan \\ Bahauddin Zakaryia University, Multan, Pakistan
}

Follow this and additional works at: https://ir.iba.edu.pk/businessreview

Part of the Social and Behavioral Sciences Commons

(c) (i)

This work is licensed under a Creative Commons Attribution 4.0 International License.

\section{Recommended Citation}

Hanif, A., \& Sultan, S. (2011). Type A-B personality and locus of control: A combined factor determining job satisfaction. Business Review, 6(2), 90-96. Retrieved from https://doi.org/10.54784/1990-6587.1195

This article is brought to you by iRepository for open access under the Creative Commons Attribution 4.0 License and is available at https://ir.iba.edu.pk/businessreview/vol6/iss2/7. For more information, please contact irepository@iba.edu.pk. 


\title{
DISCUSSION
}

\section{Type A-b Personality And Locus Of Control: A Combined Factor Determining Job Satisfaction}

\author{
Afia Hanif \& Sarwat Sultan \\ Bahauddin Zakaryia University Multan, Pakistan
}

\begin{abstract}
The present research was designed to explore the relationship of personality types; (a) Type A and B, and (b) locus of control affecting job satisfaction. A sample of 300 lecturers randomly selected from eight departments of Faculty of Arts and Social Sciences at Bahauddin Zakaryia University Multan, Pakistan, completed Anjum Khalique Type A Behavior Pattern Scale (Anjum \& Khalique, 1991), Personal Efficacy Scale (Paulhus, 1983) and General Job Satisfaction Questionnaire (Hackman \& Oldham, 1976). Results indicated that employees with a combination of personality traits of type $B$ behavior pattern and internal loc us of control report more satisfaction with their jobs than employees with type A behavior pattern and external locus of control.
\end{abstract}

Key words; Type A behavior pattern, Type B behavior pattern, locus of control, job satisfaction.

\section{Introduction}

A number of mental processes including needs, beliefs, and intentions are involved in determining a person's form of mental procedures. Mayer (2005) advocated that the way in which psychological functioning is personified in terms of one's observable societal conduct can be conveyed by personality.

Personality attribute in terms of Type A/B behavior pattern is defined as how people react when confront the stressful threats and challenges in daily life activities (Ivancevich $\&$ Matteson, 1984). People with Type A personality react to the situation in a very aggressive, achievement oriented, fast paced, assertive and impatient manner (Glazer \& Beehr, 2002). While Type B personality responds in a way characterized as free-and-easy, occasional, and leisurely in doing their assigned tasks. Regarding the locus of control of Type As and Bs many researches prove that individuals with type A behavior pattern usually have external locus of control (Spector \& O’Connell, 1994).

Social learning theory of personality put forth the idea of locus of control (Rotter, 1966). Locus of control is defined as degree to which a person believe that a performed task will give desired results. The belief of a person that one has a control over ones action leading to the outcome is termed as internal locus of control. Broadly speaking, individuals having internal locus of control have high level of self-trust, goal orientation, and make better use of chances to accomplish their tasks (Bush, 1988). On the other hand, if a person believe that the circumstances are not in favor of his activities for desired outcomes, then (s)he has external locus of control. People having external locus of control believe that their 
work is not reinforced by any internal factor, rather reinforcement comes from the external environment over which they have no control. People with external locus of control consider their behavior as instrumental and their achievements or loss to a work are controlled by events out of their reach. On the other hand people with high internal locus of control will exhibit more confidence regarding the outcomes of their efforts (Rotter, 1990).

A link between locus of control and job satisfaction was addressed by Dailey (1980). He concluded that individuals having external locus of control were more dissatisfied, have low level of participation and motivation within work settings. Job satisfaction refers to the amount of subjective state of well being derived from the performance on a job. The way in which employees comprehend the work setting refers to their job satisfaction. Workers have high level of job satisfaction if they acknowledge their work as easy and are more excited to perform work related tasks (Sarata \& Jeppersen, 1997).

It is explored in a research by Kasperson (1982), that internal locus of control is highly as sociated with job satisfaction. Broadly speaking, people who believe that the consequences of what they do is within their reach have high level of job satisfaction. A study conducted by Knoop (1981) revealed that worker's locus of control is associated with their job satisfaction. Workers who believe that there environment is in their control have better perception of their job. Peterson (1985) explored a positive correlation between external locus of control and organizational dissatisfaction. He further concluded that workers with external locus of control exclude themselves from organizational outcomes that would limit the chances of promotion and recognition in the organization.

Murdrack (1999) proposed that behavior pattern of employees is a determinant of their degree of work satisfaction. It is concluded that employees with type A behavior pattern desire to achieve complex goals, which are always out of their reach, so the result is their job dissatisfaction (Rayburn \& Rayburn, 1996). Study conducted by Choo (1986) has similar findings which proposed that employees with type A behavior pattern have higher level organizational dissatisfaction as compared to Type B employees. In his research Alarcon, Eschleman, and Bowling (2009) supported these findings that as a result of diminished work satisfaction rate of turnover is high among Type As as compared to Type Bs.

To strengthen the empirical evidences presented in review literature, the present research focused on to investigate the personality traits and locus of control determining Job satisfaction among lecturers in Pakistan. It was hypothesized that Type A behavior pattern will be positively correlated with external locus of control, and Type B behavior pattern will be positively correlated with internal locus of control. It was further assumed that employees with Type B behavior pattern and having external locus of control will report more satisfaction than employees with Type A behavior pattern and having internal locus of control.

\section{Method}

\section{Participants}

Sample consisted of 300 lecturers $(\mathrm{male}=186 \&$ female $=114)$ from eight departments of Faculty of Arts and Social Sciences at Bahauddin Zakaryia University Multan, Pakistan. Their age range was 26 to 48 years. They were more or less similar with socio economic status and cultural background. All the participants were selected through simple random sampling. 


\section{Instruments}

To achieve the objectives of the present study following instruments were after adapting according to cultural background of the participants.

\section{General job satisfaction questionnaire}

General Job Satisfaction Questionnaire originally developed by Hackman and Oldham (1976) is structured as 15 items with 5 point ratings wherein responses ranged from strongly agree to strongly disagree. Two items $12 \& 15$ are reversed scored. The maximum score is 75 and lowest is 15 . The score above 39 indicates high job satisfaction and below indicates low job satisfaction. Overall internal reliability of adapted scale is 0.77 .

\section{Anjum khalique type a behavior pattern scale}

Anjum Khalique Type A Behavior Pattern Scale developed by Anjum and Khalique (1991) consist of 12 items, and each item constitutes two statements one dealing with Type A behavior pattern whereas other with the type B behavior pattern. Statement for type A is given a score of 1 while the statement for type $\mathrm{B}$ is given a score of 0 ; hence the scores ranging from $0-12$. Scores falling between 9-12 on this scale represent type A personality and scores falling between 0-4 indicates type B personality. Overall internal reliability of adapted scale is 0.62 .

\section{Personal efficacy scale}

Personal Efficacy Scale (Paulhus, 1983) has 10 items being scored at 7-point Likert scale with responses ranging from disagree strongly to agree strongly. Scores ranged from 10 to 70 with five reversed scored items. Higher scores represents internal locus of control whereas lower scores represents external locus of control. Overall internal reliability of the adapted scale is .76 .

\section{Procedure}

For the present study 300 lecturers were randomly selected from the list of regular lecturers of the eight departments of the faculty of Arts and Social Sciences. A booklet comprising the three scales i.e. General Job Satisfaction Questionnaire, Personal Efficacy Scale \& Anjum Khalique Type A Behavior Pattern Scale along with information letter and consent form was given to participants. They were asked to fill out them with accuracy and were assured of the confidentiality of the information sought from them. Results were analyzed through SPSS (Statistical Package for Social Sciences).

\section{Results}

Mean, SD and independent sample t- test were computed in order to test the hypothesis in the present study.

\section{Table 1}

Correlation Matrix among Scales of Type A-B Behavior Pattern and Locus of Control $(\mathrm{N}=130,170)$ 


\begin{tabular}{lll}
\hline & External Locus of Control & Internal Locus of Control \\
\hline Type A Behavior Pattern & $.62 * *$ & -.019 \\
Type B Behavior Pattern & -.044 & $.749 * *$ \\
\hline
\end{tabular}

Table 1 show that Type A personality type is positively correlated with external locus of control while negatively correlated with internal locus of control. Whereas Type B personality type is positively correlated with internal locus of control and negatively correlated with external locus of control.

\section{Table 2}

Means, Standard Deviations and t-value for the Scores on Job Satisfaction Questionnaire $(\mathrm{N}=300)$

\begin{tabular}{llllll}
\hline \multicolumn{1}{c}{ Lecturers } & $\mathrm{N}$ & $\mathrm{M}$ & $\mathrm{SD}$ & $\mathrm{t}$ & $\mathrm{p}$ \\
\hline $\begin{array}{l}\text { Type As having External } \\
\text { Locus of Control }\end{array}$ & 130 & 33.85 & 3.02 & & \\
$\begin{array}{l}\text { Type Bs having Internal } \\
\text { Locus of Control }\end{array}$ & 170 & 45.32 & 4.63 & & $.000^{* * *}$ \\
\hline
\end{tabular}

$\mathrm{df},=298, \mathrm{p}<0.001 * * *$

Results depicted in Table 2 show the significant difference in levels of job satisfaction of employees having different behavior patterns and locus of control. Findings suggest that lecturers with type B behavior pattern having internal locus of control are more satisfied as compared to lecturers having type A and external locus of control.

\section{Discussion}

This research investigated the combined effect of personality traits and locus of control on job satisfaction of lecturers in Pakistan. The data was analyzed on the basis of the assumption that there would be difference in level of job satisfaction of lecturers with different behavior pattern paired with locus of control. Firstly association of personality type and locus of control was answered out by computing correlation. Results (Table 1) indicated that type Abehavior pattern is found to be combined with external locus of control, and type B is coupled with internal locus of control. It implies that employees who have been identified as type As also found to be externally oriented, and those who were with type Bs patterns have internal locus of control.

Different approaches to type A-B personality suggest that type As are competitive, achievement oriented, impatient and restless. They usually said to be confident apparently but are self doubting inside. On the other hand, Type Bs are less competitive, less hostile and more confident about outcomes of their work. Type As have external locus of control because they perceive that their life is controlled by the factors out of their control, while due to their perceived control Type Bs have internal locus of control. This perception of outcomes results into job satisfaction of internals having type B behavior pattern while job dissatisfaction of externals having type A behavior pattern. 
The hypothesis of the study stated as the lecturers with Type B behavior pattern and having internal locus of control will report more satisfaction than lecturers with Type As, and having external locus of control has been supported in this study. The results show that employees with Type A behavior pattern and having external locus of control are dissatisfied with their jobs while employees with Type B behavior pattern and internal locus of control are more satisfied with their jobs.

These findings are consistent with the findings of Kirkcaldy, Shephard, and Furnham (2002) which concluded that type A personality and an external locus of control are associated with greater perceived levels of stress and lower job satisfaction than that of employees with a type B personality and an Internal locus of control. There is a strong evidence to support a significant effect of behavior pattern combined with locus of control on work satisfaction outcomes (job satisfaction). Those with an external locus showed significantly lower level of job satisfaction, especially when this characteristic was combined with a Type A personality. It appears that negative health consequences may outweigh the superficial attractiveness of the type A personality in an employment situation, particularly when this trait is coupled with a more external locus of control

Another study reported by Spector and O'Connell (1994) also provides the support for the present research findings. They assessed personality variables to make prediction about job pressures and job stretches. They found that combination of type A personality, external locus of control, and negative affectivity, negatively influences their job satisfaction among graduating college students when they joined organizations as employees. Code and Langan-Fox (2001) also added that personality traits in terms of Type A/B can best utilized to Predict occupational health, well-being, satisfaction and performance in any work setting of employees.

\section{Conclusion}

Based on our findings, we make the following suggestions for the organizations to take out more productivity from their employees. Employees' personalities are significant in this regard. Personality traits should be considered first forth particularly when employees are complaining about their working situations and job strategies. Since many studies have debated upon personality attributes such as Type A/B behavior patterns (Bennett, 1997) and locus of control (Bodey \& Grace, 2007) to identify the factors contributing towards job satisfaction, it was not distinctly built idea that which combination of personality attributes would be helpful to understand the employees' satisfaction with their jobs. Present research is an addition towards the answer to this question for example, Type B and internally oriented employees seem to be involved in healthy activities at their work place which ultimately result in gratification and satisfaction and high productivity.

\section{Limitations \& suggestions}

Although the present study utilized the randomly selected sample to collect data, sample size is not large enough to represent whole population of employees of other industries. Some uncontrolled and unstudied variables such as gender, age, and other personality characteristics might confound the findings of study. Therefore it is suggested that this study should be replicated with a larger sample in other organizations to confirm the findings are consistent. In addition, in this study only two personality attributes Type A/B personality and locus of control are explored in terms of job satisfaction, thus the future researches can be planned with more generalized personality attributes, such as self-esteem, 
self-confidence, self-determination, self-asserting, emotional intelligence, and aggressiveness

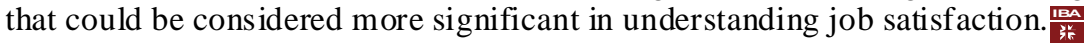

\section{References}

Alarcon G., K. J. Eschleman., and N. A. Bowling. (2009). Relationships between Personality Variables and Burnout: A Meta-Analysis, Work and Stress, 23, 244-263.

Anjum, T., and Khalique, N. (1991). Anjum Khalique Type A Behavior Pattern Scale. Journal of Behavioral Science, 2, 21-32

Bennett, R. (1997). Anger, catharsis, and purchasing behavior following aggressive customer complaints. Journal of Consumer Marketing, 14(2), 156-172.

Bodey, K., and Grace, D. (2007). Contrasting "complainers" with "non-complainers" on attitude toward complaining, propensity to complain, and key personality characteristics: A nomological look. Psychology and Marketing, 24(7), 579-594.

Bush, J. (1988). Job satisfaction, powerlessness, and locus of control. Western Journal of Nursing Research, 10(6), 718-731.

Choo, F. (1986). Job Stress, Job Performance, and Auditor Personality Characteristics, Auditing. A Journal of Practice and Theory, 5, 17-34.

Code, S., and Langan-Fox, J. (2001). Motivation, cognitions and traits: Predicting occupational health, well-being and performance. Stress and Health 17(3), 159-174.

Dailey, $R$. (1980). Relationship between locus of control, task characteristics, and work attitudes. Psychological Reports, 47, 855-861

Glazer, S., and Beehr, T. A. (2002). Similarities and differences in human values between nurses in four countries. International Journal of Cross-Cultural Management, 2, 185-202.

Hackman, J.R., and Oldham, G.R. (1976). Motivation through the design of work: test of a theory. Organization Behavior and Human Performance, 16(2), 250-279.

Ivancevich, J. M., and Matteson, M. T. (1984). A Type A-B person-work environment interaction model for examining occupational stress and consequences. Human Relations, 37, 491-513.

Kasperson, C. (1982). Locus of control and job dissatisfaction. Psychological Reports, 50, 823-826.

Kirkcaldy, B. D., Shephard, R. J., and Furnham, A. F. (2002). The influence of Type A behavior and locus of control upon job satisfaction and occupational health. Personality and Individual Differences, 33, 1361-1371.

Knoop, R. (1981). Locus of control as a moderator between job characteristics and job attitudes. Psychological Reports, 48, 519-525.

Mayer, J. D. (2005). A classification of DSM-IV-TR mental disorders according to their relation to the personality system, in J. C. Thomas and D. L. Segal (Eds.), Comprehensive 
Handbook of Personality and Psychopathology (CHOPP) (Vol. 1, pp, 443-453). Personality and Everyday Functioning. New York, NY: John Wiley \& Sons.

Mudrack, P. E. (1999). Time Structure and Purpose, Type A Behavior, and the Protestant Work Ethic. Journal of Organizational Behavior, 20, 145-158.

Paulhus, D. (1983). Sphere- specific measure of perceived control. Journal of Personality and Social Psychology, 44, 1253-1265

Peterson, N. (1985). Specific versus generalized locus of control scores related to job satisfaction. Psychological Reports, 56, 60-62.

Rayburn, J. M. and L. G. Rayburn. (1996), Relationship between Machiavellianism and Type A Personality and Ethical- Orientation. Journal of Business Ethics, 15, 1209-1219.

Rotter, J. B. (1966). Generalized expectancies for internal versus external control of reinforcement. Psychological Monographs, 80 (1, Serial No. 609).

Rotter, J. B.(1990). . , 45, 89-93.

Sarata, B. P., and Jeppersen, J. C. (1997). Job design and staff satisfaction in human service settings. American Journal of Community Psychology 5(2), 229-36.

Spector, P. A., and O'Connell, B. J. (1994). The contribution of personality traits, negative affectivity, locus of control and Type A to the subsequent reports of job stressors and job strains. Journal of Occupational and Organizational Psychology, 67, 1-12.

He had flown up very high to see, on strong wings, when he was young. And while he was up there he had looked on all the kingdoms, with the kind of eyes that can stare straight into the sun.

F. Scott Fitzgerald, The Last Tycoon 